\title{
Archaic exploitation of small mammals and birds in Northern Chile
}

BRIAN HESSE ${ }^{1}$

\section{Introduction}

The employment in modern archaeological excavations of such intensive collection techniques as sifting the site matrix through fine screens or separating the excavated material in flotation devices results in the recovery of faunal samples that include large fractions of rodent and bird bone. The presence of these taxa, often previously unrecognized as a part of the ancient cultural environment, forces zooarchaeologists to enlarge their interpretive procedures to accomodate the particular problems these species present. The samples reported here, from 15 sites in Northern Chile are illustrative cases. Most were excavated by Prof. Lautaro Núñez of the Universidad del Norte in Antofagasta, while a few were dug by Dr. Gordon Pollard of SUNY Plattsburgh.

Two areas of difficulty in interpretation are especially important. First, it is not always obvious how the various species represented in archaeological collections were exploited by ancient societies. As a result, some brief development of various hypothetical possibilities is in order. One possible avenue to interpretation could be called the "menu approach". Infrequently represented or small-sized taxa are grouped with the larger or more commonly encountered species in a dietary list. The common species are considered to be the staple resource, the infrequent to represent dietary diversification, resources providing relief from the monotony of the usual meal. While direct, such an approach makes at least two important assumptions, the validity of which may be moot.

Initially, the menu approach assumes that the primary objective in slaughtering animals is to get meat. Particularly with such animals as carnivores, rodents and birds, alternative objectives such as skins, furs, feathers and teeth need to be considered. Secondarily,

1 Department of Anthropology, University of Alabama, Birmingham, AL, 35294, ESTADOS UNIDOS. the menu aproach emphasizes the stability of tile system, diversity is seen as a resource objective in itself. The infrequent taxa are regular additions to the diet. Perhaps selection of particular species is conditioned by seasonal variations to availability, but the over-riding interpretations is that a cultural goal is a well-rounded diet. This approach may be solidly based, since nutrition research has shown how complex mixes of foods may be necessary to fulfill human dietary needs. It may be that the ancient complex menus offered as yet unrecognized selective advantages. However, the menu approach is probably most applicable to settings of relative resource plentitude and environmental stability, where the costs of pursuing the less common species are not economically significant (i.e., the usual resources are not thereby neglected). Alternatively, the menu approach would be useful in settings where, while plant foods may be plentiful, protein is less abundant, and meat a year-round critical resource. Parenthetically, it is important to note that it will probably be difficult to recognize these situations archaeologically on the basis of the faunal remains. While we may be able to estimate the relative contribution to the diet of the various species, average annual consumption by the individuals in ancient societies will probably nave to be reconstructed from ethnohistorical or ethnoarchaeological sources (Gilbert 1979).

As an alternative to the menu approach, Wilkinson's (1975) concept of the buffer resource is a valuable interpretive tool in estimating the importance of the less frequently represented taxa recovered in archaeological excavations. A buffer resource is a food, never attractive enough to encourage extensive investment in time or equipment, but reliable and common enough to act as an insurance comestible during times when calamity strikes the usual food producing activities. That is, if the fishermen fail to produce a catch, the hunters bag no game, or the herdsmen's flocks are destroyed by weather or disease, these other foods, rodents and birds, take on short-term importance as meat suppliers. Wilkinson 
formulated his concept in the context of the analysis of Arctic and Subartic societies, cultures exploiting environments sharing some similarities with Northern Chile. Of particular note is the restricted number of potentially exploitable animal resources compared to more temperate regimes. Biocoenoses of this type are especially susceptible to wide oscillations in biomass brought on by environmental variability. Druss (1977) has summarized the climatic information for the Atacama region concluding that the area experienced irregularly shifting habitat distributions during the Archaic Period, a tentative result that suggests that protein availability may have varied as well. Buffer resources are also important to cultures that have made any significant investment in the architecture of their habitations or are tied to specific locations because of the need to exploit non-biological materials, for example, flint outcrops. These groups would tend to turn to buffer resources as a way to avoid new investment of capital and labor or to avoid having to locate new areas to mine.

The second area of interpretive difficulty concern» the fact that it is not always possible to determine the agent of accumulation responsible for the deposition of rodent and bird bones in archaeological sites (Binford 1980). Animal bone collections are the result of the complex interaction of natural as well as cultural factors (Hesse 1982a). Man Bay not be presumed to have been the accumulator simply because a plausible cultural reason for rodent or bird species being present can be offered. Two paths out of the problem have been developed. One is to examine the skeletal recovery pattern for each taxon. While this approach is plagued by the difficulty in positively identifying many of the bones of a wide variety of species (taxonomic work has not, in roost cases, concentrated on the post-cranial bones), if the recovery frequencies for the various bone types compare favorable to ethnographically derived expectations, the presumption of human involvement is strengthened. The second path out of the problem has been suggested by Thomas (1971). He applied Shotwell's (1958) concepts developed for palaeontological research to archaeological collections. For Thomas, if the bones of a species are widely dispersed in the site matrix with few certain articulations or partial skeletons found, then that species is more likely to have been utilized by the ancient inhabitants. Species that are recovered as nearly complete skeletons or in concentrated deposits are less likely to have been human resources. Of course even these latter species may be important to archaeological interpretation as evidence for environmental conditions (presuming that the problems of associating burrowing animals with cultural strata can be overcome).

These introductory comments are intented to convey a sense of the difficulty in interpreting the ordent and bird bones found in archaeological sites. What follows is a description of the material found in a number of archaeological sites in Northern Chile. In not all cases has it been possible to deal with the twin problems of resource use and agent of accumulation. Future solutions will require considerable additional data about the recovery patterns for the various species in archaeological sites and ethnographic accounts of their utilization, as well as detailed information about the depositional history of a site so that the intertwined effects of culture and nature may be unravelled.

Excavations by Núñez at the sites of Tiliviche, San Lorenzo, Tuina, Tilomonte, Tambillo, Puripica, Pozo Cavado, Tulan 51, Tulan 52, Tulan 54, Tulan 55, and Tulan 56 produced $c a$. 122.000 bone fragments of which $c a .22000$ were identifiable fragments of mammals and birds. Calculations of the average fragment size in the Tulan 52 collection indicates that the mean specimen weight was slightly less than $2 \mathrm{gr}$ (59149 fragments weighing $113.615 \mathrm{gr}$ ). Taken together with the skeletal recovery pattern for the rodents and birds, it la likely that the minimum specimen size reliably recovered (Watson 1972) is larger than the post-cranial bones of the smallest rodents present but smaller than the limb bones of the medium sized and large rodent species encountered. Since Núñez has been consistently applying his efficient collection techniques at all of his excavations, it can be assumed that this minimum specimen size applied to all his samples. An additional nearly 900 identifiable mammalian and avian bone fragments were recovered from RAnL 100, 273A-1, and 337-1 in the excavations conducted by Pollard in the río Loa region. These 15 samples provide the basis for this report. The material is divided geographically and temporally for presentation below.

\section{Northern Region}

The site of Tiliviche is located about $40 \mathrm{~km}$ inland at an elevation of $950 \mathrm{~m}$ on the side of the quebrada Tiliviche. The site covers more than $4000 \mathrm{~m}^{2}$ and excavations were conducted in two major areas. Occupation, on the basis of radiocarbon determinations 
flourished from about 8000 or 10000 years ago to 6000 years ago (Nuñez Ms). The primary protein resources at the site were marine. About $82 \%$ of the remains recovered were fish bones and shell fragments (Table 1). A few additional specimens of bone nave been tentatively identified as sea lion. Terrestrial taxa included small carnivores, camelids and possibly cervids among the larger mammals. Some as yet unidentified avain material was recovered. Provisional examination suggests that such sea birds as cormorant and pelican are present. The most interesting of the less frequent taxa, however, are the 62 bone fragments of Caviidae, the family which includes the cavies or guinea pigs. The skeletal representation of this taxon is given in Table 2 which indicates that while skull and mandible are the most frequent, the rest of the skeleton is represented. In order to illustrate the degree of dispersion of the cavy sample, two plans are provided. These refer to only one of the excavated areas, which produced 31 of the cavy bones. The first plan shows the density of faunal debris in the site. Bone recovery counts per square were calculated and denser patches are indicated by different graphic codes. Two dense areas, one on the right of the diagram, the other on the left were detected. This result is largely an artifact of the depth of deposit. The second plan, which illustrates the dispersion of Cavy bones, shows a wide spread of mostly single specimens with the only two concentrations in the two richest squares in the excavation. This tentatively suggests that human activities were responsible for the accumulations.

Certainly cavies were an important resource in ancient Andean cultures and continue to be an important resource today. Bolton (1979) provides an excellent ethnographic summary of the species

\begin{tabular}{|l|r|l|}
\hline \multicolumn{1}{|c|}{ Taxon } & \multicolumn{1}{c|}{$\mathbf{N}^{\mathbf{0}}$} & \\
\hline Fish & 3686 & \\
\hline Shell & 1786 & \\
\hline Mammal & & \\
\hline Rodent & 62 & \\
\hline Carnivore & 23 & $\begin{array}{l}\text { (Incluides sea lion, for and small } \\
\text { carnivore) }\end{array}$ \\
\hline Medium sized & & $\begin{array}{l}\text { (Incluides 343 positively identified } \\
\text { camelid, Lama sp., fragments) }\end{array}$ \\
\hline Bone scrap & 642 & \\
\hline Total & $\mathbf{6 7 1 4}$ & \\
\hline
\end{tabular}

Table 1. Distribution of faunal materials in the Tiliviche sample.

\begin{tabular}{|l|r|}
\hline Crania & 16 \\
\hline Maxilla & 9 \\
\hline Mandible & 17 \\
\hline Vertebra & 1 \\
\hline Scapula & 2 \\
\hline Ulna & 1 \\
\hline Innominate & 8 \\
\hline Femur & 4 \\
\hline Tibia & 3 \\
\hline Shaft fragment & 1 \\
\hline \multicolumn{1}{|c|}{ Total } & $\mathbf{6 2}$ \\
\hline
\end{tabular}

Table 2. Cavia skeletal representation in the Tiliviche sample.

exploitation in one area of Peru, arguing specifically that the species' utilization is tied to the ritual cycle. Here the animal is clearly a buffer resource. Bolton observes (1979: 249), "the meat is eaten on specified occasions during the season when dietary deficiencies are likely to be greatest". To manage this need for irregular dependence on cavy meat, the husbanded flocks undergo tremendous variation in size throughout the year, the reproductive abilities of the rodent being relied on to rapidly generate a significant resource (only about 3-4 months are required to raise one to slaughter size). Therefore there is reason to inquire if the animal might have been domesticated at Tiliviche.

The evolutionary history of the domestic cavy is a complex subject. However, most authorities agree that the domestic species Cavia porcellus derived from the genus (or subgenus) Cavia. The difficulty is that another form, the species Galea musteloides, which is closely similar to Cavia, is present in Northern Chile in the wild, while examples of Cavia are not (Pearson 1951: 152-153). An osteological distinction in the cranium separates the two forms. The single Tiliviche crania on which this characteristic could be observed seems to match the Cavia morphology. While the date for the exploitation of guinea pigs at Tiliviche is in rough agreement with dates for the species domestication in the central Andean valleys, additional corroboration would be attractive. Ijzereef (1978) has published two criteria for determining if domestic guinea pigs are present in archaeological samples. The first, based on estimates of guinea pig mortality, requires large numbers of tooth rows, and could not be used. Also, however, he suggested that the shape of the notch in the ilium may be diagnostic. 
The Tiliviche specimens are similar in shape to the form of this "transitional" category, intermediate between wild and domesticated forms.

The Tiliviche evidence is tantalizing. Perhaps here we have an episode of very early cavy domestication, possibly for use as a buffer resource in periods of poor fishing, if the ethnographic model from Peru has any local validity.

\section{Atacama Region}

The 14 sites in the sample from the Atacama region belong to three periods of occupation. Two small samples, from Tuina and San Lorenzo, have been doled by radiocarbon determinations to approximately 10000-11000 years ago (Núñez Ms). A second group of sites including Tulan 51, Tulan 52, Tulan 54, Tulan 55, Puripica, Tambillo and Tilomonte represented archaic occupations ca. 5200 to 3600 years ago. The other sites, Pozo Cavado, Tulan 56, and the rio Loa material, are all either Ceramic Period sites or have historic materials in their samples. The material from all these sites is presented in a series of tables appended to this report.

\section{Avian taxa}

Though some additionai specimens from several sites have not yet been identified, and therefore the species list ubdoubtedly will be slightly expanded eventually, eight taxa from these sites can be specified.

Pterocnemia pennata (Lesser Rhea). A couple of phalanges derive from the Lesser Rhea, a large flightless species that occupies open highland grasslands (Meyer de Schauensee 1970: 2).

Podidepediformes (Grebe). A member of the Grebe family is respresented. On distributional grounds either Podiceps taczanowski or Centropelma micropterum both known from the Puna zone, are possibilities. These species are occupants of freshwater ponds and lakes (Meyer de Schauensee 1970: 10-11).

Tinamotis pentlandii (Puna Tinaniou). The collection of tinamou bones can be referred to a large species of this ground bird. On zoogeographic grounds as well the Atacama specimens can be assigned to Tinamotis pentlandii. These birds inhabit blushy country where they nest on the ground feeding on fruit, seeds and insects. The adults are about $46 \mathrm{~cm}$ in length (Meyer de Schauensee 1970: 3-9).
Phoenicopteridae (flamingoes). Three species of flamingo, two large (more than $115 \mathrm{~cm}$ ); Phoenicopterus chilensis, the Chilean flamingo, and Phoenicoparrus andinus, the Andean flamingo, and one small: Phoenicoparrus jamesi, the Puna flamingo, inhabit the shallow lakes of the Puna. Due to the fragmentary nature of the archaeological material and the lack of reference material, it was not possible to divide the material among them. All are inhabitants of the highland salt lakes in summer, often wintering at lower elevations in salt marshes (Meyer de Schauensee 1970: 28-29).

Fulica sp (coot). The Atacama samples include bone fragments from large species of the coot family. These birds are residents of highland alkaline lakes, have slaty black plumage, and tend to run rather than fly when alarmed. The two roost likely species are Fulica gigantea, the giant coot, and $F$. cornuta, the horned coot (Meyer de Schauensee 1970: 70).

Anas sp. (duck). A series of bone fragments could be assigned to the ducks. Of the reference material it was possible to see, the collection compared best to Anas flaviostris, the speckied teal, but on zoogeographic grounds. Anas puna, the Puna teal, would also be a logical possiblity. Both would frequent mountain lakes (Meyer de Schauensee 1970: 33-34).

Chloephaga cf. melanoptera (Andean goose). A few specimens could be assigned to Chloephaga $\mathrm{cf}$. melanoptera, the Andean goose, a large $(\mathrm{ca} .65 \mathrm{~cm})$ occupant of Andean lakes and marshes. This species breeds at altitudes over $3000 \mathrm{~m}$ but winters at lower elevations (Meyer de Schauensee 1970: 32).

Metriopelia sp. (ground dove). The specimens of Columbidae (pigeons and doves) in the collection compare best to the genus Metriopelia, one of the ground doves. On zoogeographic grounds, M. ceciliae, M. aymara, or M. melanoptera are all possibilities. The three are small ground birds that are attracted to cultivated land and villages.

\section{Rodent taxa}

Though some additional rodent material remains to be identified, the overwhelming bulk of the Atacama rodent material can be referred to five taxa.

Chinchillidae (vizcachas and chinchillas). Two members of the Chinchillidae family are present in the Atacama samples. The larger of the two, 
Lagidium viscacha, the mountain vizcacha, is a diurnal and gregarious occupant of rocky areas. They are valuable for their fur and their meat, some adult individuals weighing perhaps $2 \mathrm{k}$. The smaller of the two is Chinchilla laniger, a species famed for its fur that occupies elevations from about 3000 to $5000 \mathrm{~m}$. They are gregarious being roost active in the early morning and late evening (Walker 1975: 1031-1032). They weigh 500 to $800 \mathrm{~g}$. Though quite similar in skeletal morphology, the considerable size difference between the two permitted separation osteometricably. Figure 3 provides a histogram of the measurements of the length of the tooth rows. In sample with a significant number of measureable specimens it was possible to estimate the relative frequency of the two taxa.

Ctenomys fulvus (tuco tuco or cholulo). This species was described by R.A. Phillipi whose original watercolors of the species in the collections of this museum. The tuco tuco is a gregarious, fossorial, diurnal rodent which prefers the soft soils and salt resistant plants of the areas adjacent to saline lakes (Pearson 1959).

Phylottis cf. darwini (leaf-eared mouse). The leafeared mouse is an occupant of rocky places where it seems to be active nocturnally (Pearson 1951: 143).

Abrocoma cf. cinerea (chinchilla rat). The chinchilla rat is a resident of high altitudes ( 3700 to $4900 \mathrm{~m}$ ) (Pearson 1951: 158; but see Osgood 1943: 106) where they are occupy burrows and live gregariously.

\section{Archaeological distribution}

The two early Archaic Atacama sites, Tuina and San Lorenzo, have strinkingly different faunal assemblages. Tuina has a much greater proportion of camelid bone than the latter site. The two also contrast in terms of their rodent distributions. The skeletal representation of the most frequent taxon in each site, Lagidium/Chinchilla, is different. The San Lorenzo sample has nearly anatomical proportions of the different bone types; Tuina has only two skeletal elements represented. Taken together with the observation that the site matrix had a considerable amount of rodent coprolites (Núñez Ms) and Walker's note (1975) about the nature of chinchilla fecal material, the skeletal distribution suggests that the San Lorenzo rodent sample may be natural in origin. Rather the artifact and botanical remains inventory may, as Núñez notes may be a good guide to the nature of the occupation, probably a plant processing location. The Tuina sample probably better reflects the occasional nature of vizcacha/ chinchilla exploitation in the Early Archaic.

The second group of sites, those dating from about 5200 to 3600 years ago, has by far the largest sample of rodent and bird bone material in our collections. Elsewhere (Hesse 1982b, 1983c) evidence has been presented demonstrating that distinct patterns of camelid exploitation are derivable from the three largest samples in the group of sites -Tulan-52 appears to nave been a hunter's habitation stationed in a strategic location along one of the quebradas linking the highlands to the Salar; Puripica appears to have been a hunting/pastoral occupation where consumption of hunted small camelids was supplemented with meat from herded large camelids. It was further argued that this pattern emerged as a response to oscillating levels of game availability Tambillo seems to have been a hunting station though, as shown below, camelids were less important.

Examination of the distribution of the rodent remains from this group of archaic sites provides additional evidence of cultural variability, The Tambillo sample is the most striking. Ctenomys is incredibly common, represented in the sample by 969 bone fragments (Table 9). The skeletal distribution of this species is dominated by cranial elements, a pattern reconcilable with the method of consuming these rodents reported to me by Olaff Olmos based on his experiences and conversations with some of the men of San Pedro de Atacama. Butchering and preparation of these animals can be simple, lop of the head and roast. The archaeological effect of this activity is that the heads tend to be preserved differentially, while postcranials, softened by the cooking are lost. Considerably more limb elements would be expected if carnivores were responsible for the accumulation. The exploitation of this species was supplemented by the utilization of vizcacha, based on the few measureable mandibles in the Chinchillidae sample.

In the Tulan 52 samples (Table 14), a different pattern is present. About $85 \%$ of the sample is Chinchillidae, the remainder being almost exclusively Ctenomys, Of the Chinchillidae, about 94\% is chinchilla, with only $6 \%$ vizcacha. At Puripica (Table 11) about $94 \%$ of the sample in Chinchillidae but only $57 \%$ of the 


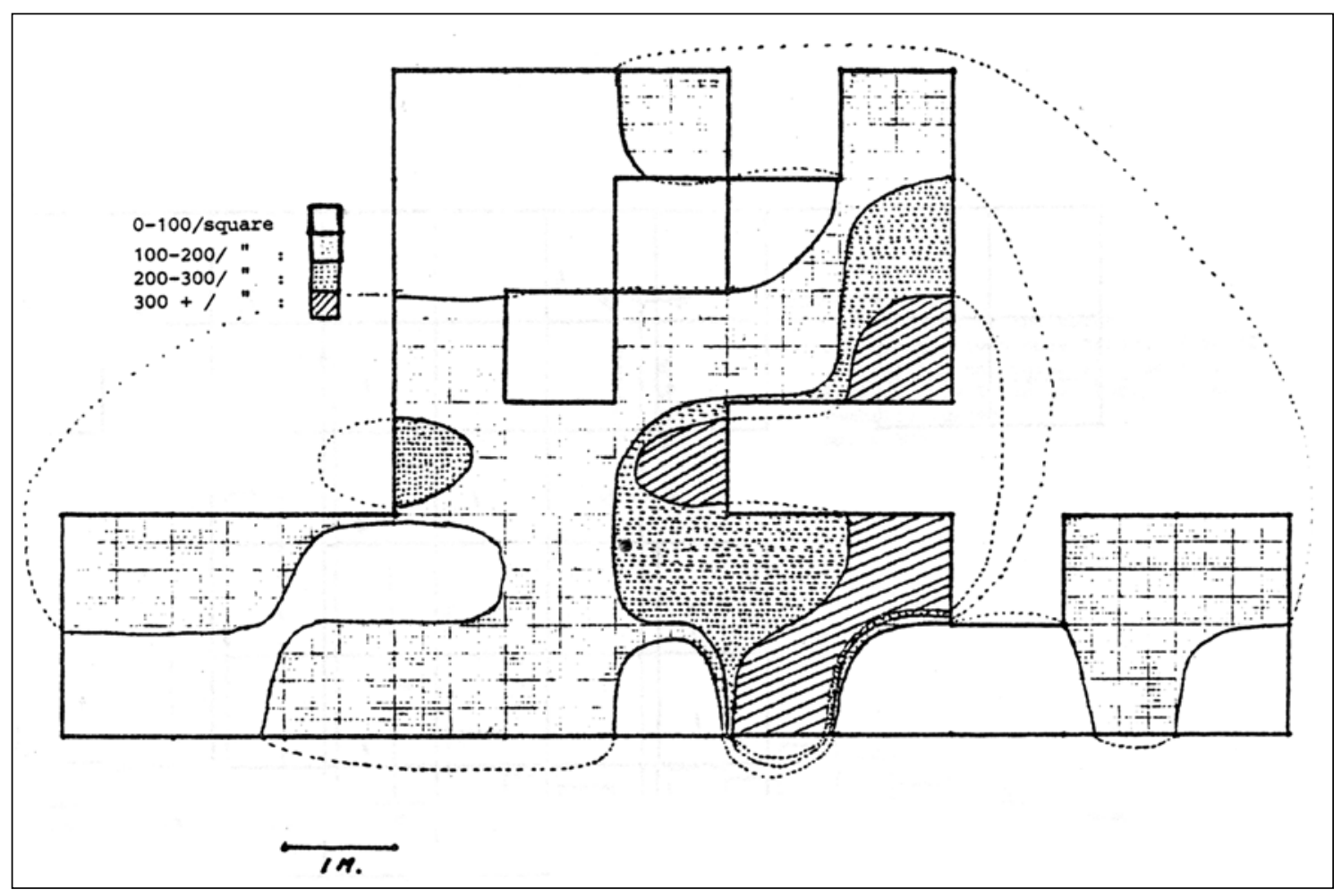

Figure 1. Tiliviche. Bone/shell recovery frequencies.

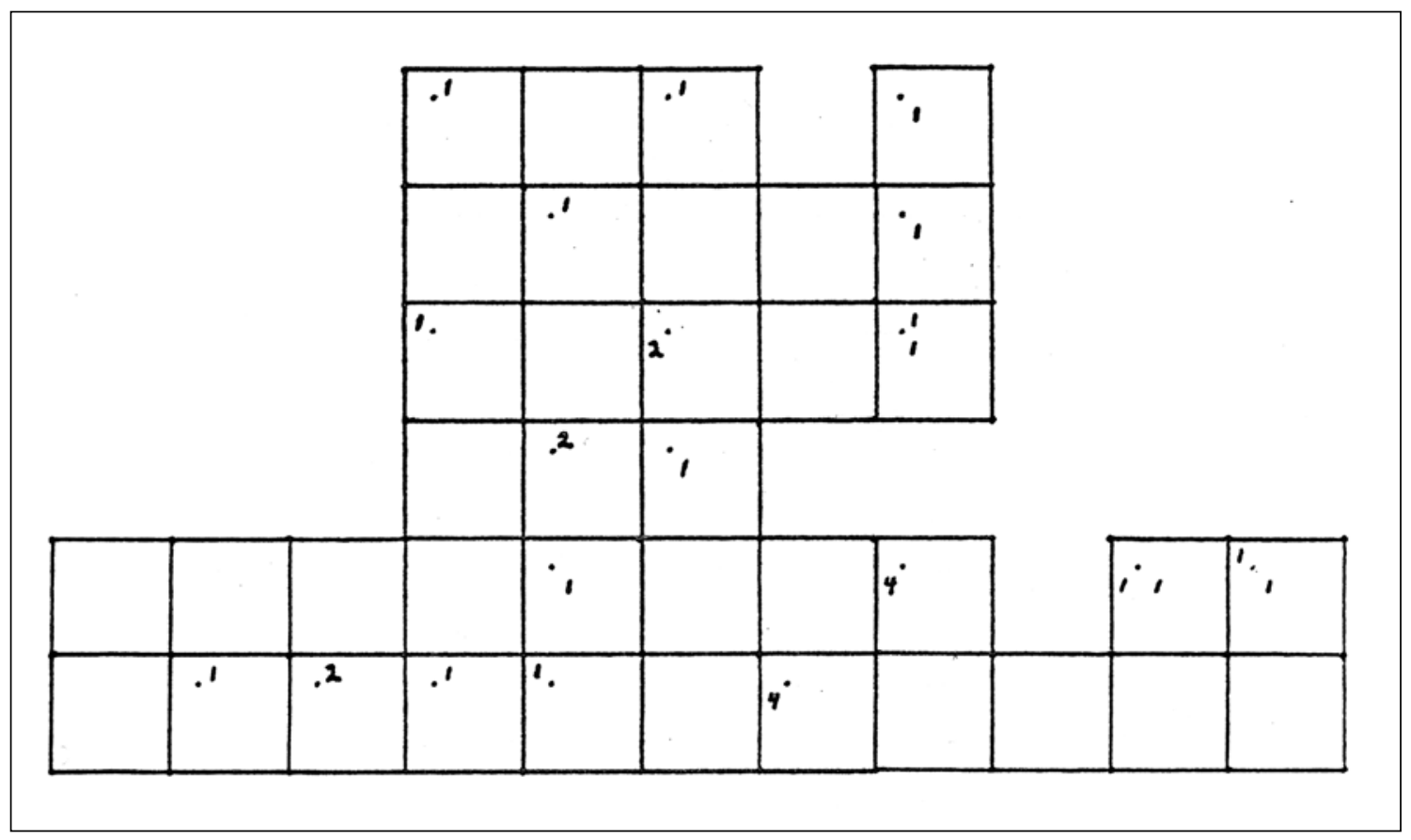

Figure 2. Tiliviche Cavia. 


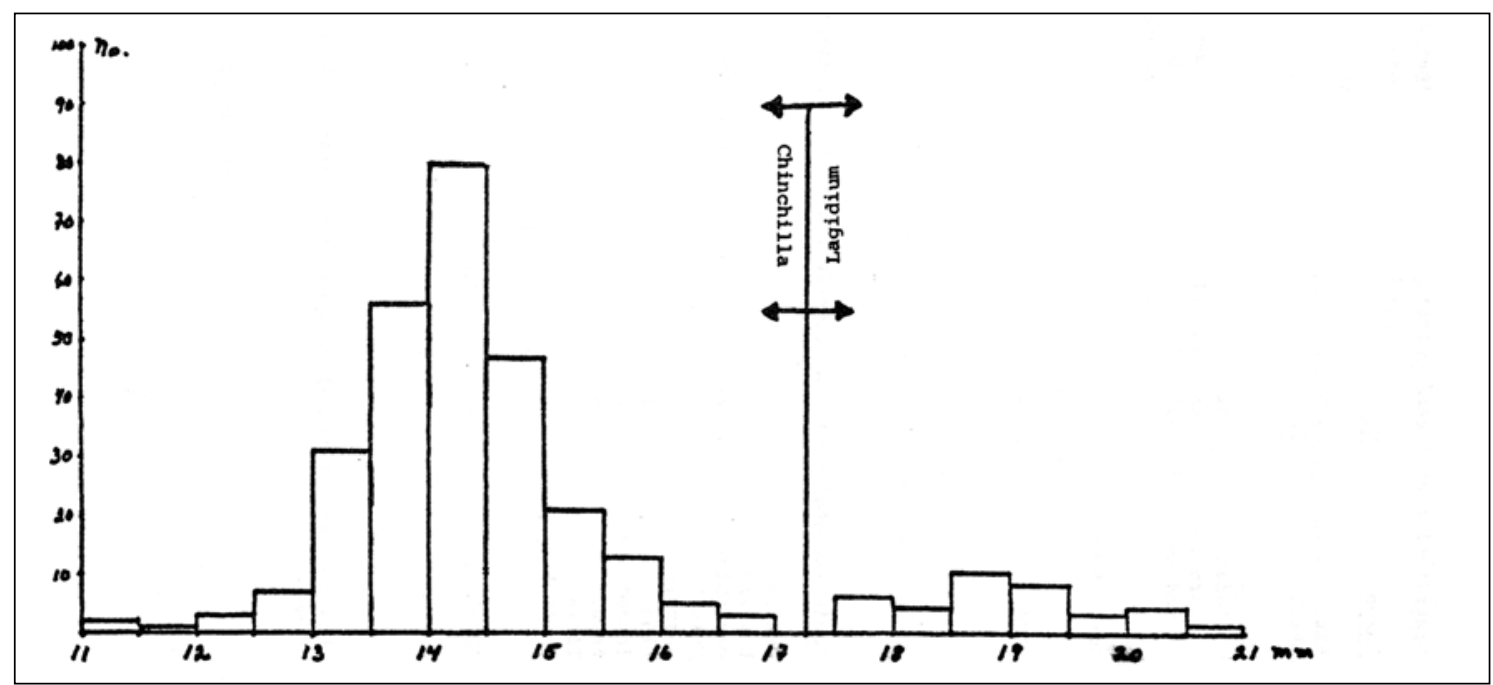

Figure 3. Distribution of the tooth row lengths (von does Dresch, Meas. \#2) in Lagidium and Chinchilla mandibles. Samples from Tulan 52, Puripica, and Tambillo lumped. $\mathrm{N}^{\circ}=305$.

\begin{tabular}{|l|c|c|}
\hline \multicolumn{1}{|c|}{ Taxon } & Tuina & San Lorenzo \\
\hline Mammal & & \\
\hline Camelids & 25 & 5 \\
\hline Rodents & 16 & 59 \\
\hline Bird & & \\
\hline Bone scrap & 318 & 40 \\
\hline Total & $\mathbf{3 5 9}$ & $\mathbf{1 0 8}$ \\
\hline
\end{tabular}

Table 3. Distribution of faunal remains in the Tuina and San Lorenzo samples.

sample is chinchilla, the percentage of vizcacha being seven times higher than at Tulan 52. At both sites small amounts of Phyllotis and Abrocoma bones are not suggestive of any particular interpretation.

The other much smaller samples from the Archaic Atacama sites provide additional information. The tiny sample from Tilomonte (Table 5a) contains three tuco tuco mandibles, expectable given the location of the site near the Salar. The Tulan 51 site (Table 12), a flint knapping station (Núñez, pers. comm.) has, despite a very large number of bone fragments, only one rodent bone, that from a vizcacha or chinchilla, compared to 191 camelid fragments. Tulan 54 (Table 10), with substantial numbers of vizcachas/ chinchillas appears to parallel the Tulan 52 sample. Tulan 55 (Table 18) contains a higher proportion of tuco tuco and the largest sample of the small rodent
Phyllotis. However, this last species is suspect as a human resource since the remains are concentrated in pockets In the deposit, a pattern that suggests predatory bird accumulations.

The later period sites contrast between the Tulan region and the rio Loa. Only one of the latter group of sites produced rodent material, RaNL-100, and in very small quantities. In the Tulan region. Pozo Cavado, a site located at a higher elevation to the east of Tulan 52, produced a large sample of rodent bones, most of which were Chinchillidae, one third vizcachas and two thirds chinchillas.

Turning to the bird remains, only four unidentified bird bone fragments have been recovered for the early period, all from San Lorenzo. In the Middle Period, again there are several patterns. At Tambillo (Table 9), the identified sample is almost exclusively ground-dove though a few leal bones are present. The large category of "bird" sterni derive from an as yet unidentified species of pigeon size or smaller. At Puripica (Table 11) the sample is dominated by flamingoes with about half as many coots, and doves, a quarter as many tinamous. a few geese and two toe bones of the rhea. The Tulan 52 sample is similar to the Puripica material though coots and rheas are absent and a grebe bone is present (Table 14). The remaining Atacama sites have a sprinkling of bird bones but no sample is large enough to betray a pattern. A similar situation is reflected in the rio Loa and other Ceramic Period sites. 


\begin{tabular}{|c|c|c|c|c|c|c|c|c|}
\hline \multirow{3}{*}{ Bone } & \multicolumn{8}{|c|}{ Taxon } \\
\hline & \multicolumn{2}{|c|}{ Lagidium/ Chinchilla } & \multirow{2}{*}{$\begin{array}{c}\text { Abrocoma } \\
\text { San } L\end{array}$} & \multicolumn{2}{|c|}{ Small rodent } & \multicolumn{2}{|c|}{ Rodent } & \multirow{2}{*}{$\begin{array}{c}\text { Bird } \\
\text { San L }\end{array}$} \\
\hline & $T u$ & San $L$ & & San $L$ & & $T u$ & $\operatorname{San} L$ & \\
\hline Cranium & & 8 & & & & 1 & 2 & \\
\hline Mandible & 3 & 6 & 2 & & 1 & 2 & 1 & \\
\hline Maxilla & & 5 & & & & & & \\
\hline Teeth & & 2 & & & & & & \\
\hline Scapula & & 9 & & & & & & \\
\hline Humerus & & & & & & & 1 & \\
\hline Radius & & 1 & & & & & & \\
\hline Innominate & 4 & 6 & & & 1 & & & \\
\hline Tibia & & 5 & & & & & 1 & \\
\hline \multicolumn{9}{|l|}{ Metapodial } \\
\hline Rib & & & & & & 2 & 1 & \\
\hline Sternum & & & & & & & 2 & \\
\hline Shaft frag. & & & & & & 4 & 6 & \\
\hline Vertebra & & 1 & & & & 2 & & \\
\hline Total & 7 & 43 & 2 & & 2 & 9 & 12 & 4 \\
\hline
\end{tabular}

Table 4. Distribution of skeletal representation in the Tuina and San Lorenzo rodent and bird sample.

\begin{tabular}{|l|c|}
\hline \multicolumn{1}{|c|}{ Taxon } & $\mathbf{N}^{\mathbf{0}}$ \\
\hline Mammal & 8 \\
\hline Camelid & 4 \\
\hline Rodent & 1 (Dusicyon) \\
\hline Camelid & 1 (pigeon sized) \\
\hline Bird & 42 \\
\hline Bone scrap & $\mathbf{5 6}$ \\
\hline \multicolumn{2}{|c|}{ Total } \\
\hline
\end{tabular}

Table 5. Distribution of faunal remains in the Tilomonte sample.

\begin{tabular}{|l|c|c|c|}
\hline \multirow{2}{*}{ Bone } & \multicolumn{3}{|c|}{ Taxon } \\
\cline { 2 - 4 } & Ctenomys & Phylottis & Bird \\
\hline Mandible & 3 & & \\
\hline Maxilla & & 1 & \\
\hline Synsacra & & & 1 \\
\hline
\end{tabular}

Table 5a. Distribution of skeletal representation in the Tilomonte rodent and bird sample.

\begin{tabular}{|c|r|}
\hline Taxon & $\mathbf{N}^{\mathbf{0}}$ \\
\hline Mammal & 1 \\
\hline Rodent & 146 \\
\hline Camelid & 384 \\
\hline Bird & 9 \\
\hline Bone scrap & 1574 \\
\hline Total & $\mathbf{2 2 1 4}$ \\
\hline
\end{tabular}

Table 6. Distribution of faunal materials in the Pozo Cavado sample.

\section{Discussion}

What interpretations can be drawn from this material. One obvious point is that the rodent remains are predictable given the location of the sites. Chinchillidae are common in the rocky quebradas, tuco tucos near the Salar. The bird remains point to the exploitation of the Puna regions to the east of the Salar de Atacama Basin. This interpretation agrees with the pattern determined from the camelid remains. The hunted smaller camelids, if vicunas, would have been more common at the higher elevations. The two were probably exploited together.

A more complex hypothesis involving the concepts of buffer resourcess and resource stress can be induced frona the rodent distributions. One curious absence is the lack of flamingo remains at Tambillo. If the site represents an occupation in the expectable nomadic round, up to the Puna in the summer, down to the Salar in the winter, then flamingoes should nave been an occassionally available resource. They are not though the ubiquitous ground dove was taken. Second, if the chinchilla and the vizcacha were actually pursued for different primary reasons: the vizcacha, a diurnal rodent, for its meat first, then for its fur while the chinchilla, a nocturnal rodent, was taken first for its fur, then for its meat, a contrast between Tulan 52, en the one hand, and Puripica and Pozo Cavado, on 


\begin{tabular}{|c|c|c|c|c|c|}
\hline \multirow{2}{*}{ Bone } & \multicolumn{5}{|c|}{ Taxon } \\
\hline & Lagidium/Chinchilla & Ctenomys & Abrocoma & Rodent & Bird \\
\hline Crania & 13 & & & & \\
\hline Teeth & 20 & 6 & & & \\
\hline Mandible & 30 & 2 & 1 & 1 & \\
\hline Maxilla & 8 & 3 & & & \\
\hline Scapula & 7 & & & & 1 \\
\hline Humerus & 2 & & & 1 & \\
\hline Radius & 4 & & & & 1 \\
\hline Innominate & 5 & & & 1 & \\
\hline Femur & 1 & & & & \\
\hline Tibia & 7 & & & & \\
\hline Metapodia & 5 & & & 1 & \\
\hline Sternum & & & & & 7 \\
\hline $\mathrm{Rib}$ & 4 & & & 3 & \\
\hline Phalanx & 1 & & & & \\
\hline Shaft fragments & 3 & & & 17 & \\
\hline Total & 110 & 11 & 1 & 24 & 9 \\
\hline
\end{tabular}

Table 7. Distribution of skeletal representation in the Pozo Cavado rodent and bird sample.

\begin{tabular}{|c|r|}
\hline \multicolumn{1}{|c|}{ Taxon } & $\mathbf{N}^{\mathbf{0}}$ \\
\hline Mammals & 1047 \\
\hline Camelid & 1059 \\
\hline Rodent & 146 \\
\hline Bird & 93 \\
\hline Bone scrap & 24945 \\
\hline Total & $\mathbf{2 7 1 2 6}$ \\
\hline
\end{tabular}

Table 8. Distribution of faunal materials in the Tambillo sample.

the other emerges, fhe hunting Site, Tulan 52, relies on the Chinchillidae almost exclusively on the fur end of the spectrum; both pastoral sites emphasize more the meat end of the continuum. Both observations are explainable if the phenomena are seen as responses to resource stress. Tambillo might well be a summer, rather than a winter occupation, and the heavy exploitation of tuco tucos a response to a failure or the usual camelid hunting at higher elevations. The increased exploitation of the meaty Chinchillidae by the pastoralists can be seen both as a feature of the process that caused them to adopt the technology, irregular resource availability leading to the adoption of insurance herds (Hesse 1982b), and a characteristic of the herding way of life, the general disinclination among pastoralists to slaughter their stock and so decrease their productive capital.

A third comment can be offered, rodent and avian remains are exceedingly rare in three of the sites reported on here-Tulan 51 and the two rio Loa sites, 273 A-1 and 337-1. The first of these, as mentioned above, is a chipping station, while the rio Loa sites, on the basis of the camelid material, are specialized animal processing accumulations (the samples from both are dominated by cranial and foot bones, the meat bearing skeletal elements are absent). It can be suggested as a hypothesis here that specialized settlements are likely to be poorly endowed with the remains of buffer resources. They should contrast with base camp settlements where the investment in the more permanent habitations makes the occupants more reluctant to leave.

\section{Conclusions}

This brief resume of the rodent and avian remains from archaeological sites in Northern Chile was intended to illustrate a number of related points. First, the nature of human utilization of many smaller taxa is not always obvious. Further, the motivation that leads societies to invest time and effort in the pursuit of these often small packages of resource is 


\begin{tabular}{|c|c|c|c|c|c|c|}
\hline Bone & Ctenomys & Lagidium/Chinchilla & Rodent & Metripelia & Anas & Bird \\
\hline Mandible & 669 & 9 & 1 & & & \\
\hline Maxilla & 251 & 1 & & & & \\
\hline Teeth & & 3 & & & & \\
\hline Crania & 26 & 10 & 48 & & & \\
\hline Scapula & 2 & 3 & & & & \\
\hline Humerus & & 2 & 1 & 6 & 4 & \\
\hline Radius & 4 & 2 & & & & 1 \\
\hline Ulna & 2 & 1 & & 5 & & 1 \\
\hline Innominate & 5 & 1 & & & & \\
\hline Femur & 4 & 1 & 1 & 1 & & \\
\hline Tibia & 4 & & 1 & & & \\
\hline Metapodia & & & 2 & & & \\
\hline Vertebra & 2 & & & & & \\
\hline Rib & & & 3 & & & \\
\hline Furcula & & & & & & 6 \\
\hline Sternum & & & & 4 & & 32 \\
\hline Carpo-metacarpus & & & & 4 & & \\
\hline Coracoid & & & & 5 & 1 & \\
\hline Tarso-metatarsus & & & & 1 & & \\
\hline Tibiotarsus & & 3 & & 3 & 3 & \\
\hline Shaft fragments & & & & & & 18 \\
\hline Total & 969 & 33 & 57 & 29 & 6 & 58 \\
\hline
\end{tabular}

Table 9. Distribution of skeletal representation in the Tambillo rodent and bird sample.

\begin{tabular}{|l|c|}
\hline \multicolumn{1}{|c|}{ Taxon } & \multicolumn{1}{c|}{$\mathbf{N}^{\mathbf{0}}$} \\
\hline Mammal & 3426 \\
\hline Camelid & 825 (does not include unidentified fragments) \\
\hline Rodent & 1 (Felis concolor) \\
\hline Carnivore & 143 (does not include unidentified fragments) \\
\hline Bird & ca. 16000 \\
\hline Bone scrap & ca. $\mathbf{2 0 3 8 5}$ \\
\hline \multicolumn{1}{|c|}{ Total } &
\end{tabular}

Table 10. Distribution of faunal remains in the Puripica sample

multi-faceted. Second, the causes surrounding the deposition of small taxa in archaeological sites are not always clear. Natural and cultural phenomena combine to create sites. Finally a pair of tentative hypotheses have been offered to explain the observed patterns of rodent and bird bones in the various sites in the hope that they may encourage future work.
Acknowledgements The research reported in this paper was supported by grants from the Smithsonian Institution and the University of Alabama in Birmingham. I am extremely grateful to Lautaro Núñez for entrusting his collections to my care, and providing counsel in the formation of the ideas presented here. A considerable debt of gratitude is 
ARCHAIC EXPLOITATION OF SMALL MAMMALS AND BIRDS IN NORTHERN CHILE

\begin{tabular}{|c|c|c|c|c|c|}
\hline \multirow{2}{*}{ Bone } & \multicolumn{5}{|c|}{ Taxon } \\
\hline & Lagidium/Chinchilla & Ctenomys & Abrocoma & Phylottis & Rodent \\
\hline Mandible & 162 & 11 & 8 & 14 & \\
\hline Maxilla & 76 & 2 & 2 & 1 & \\
\hline Teeth & & 2 & 2 & & \\
\hline Crania & 36 & 2 & & & 29 \\
\hline Scapula & 43 & 2 & & & \\
\hline Humerus & 78 & & & & \\
\hline Ulna & 35 & & & & \\
\hline Radius & 40 & & & & \\
\hline Innominate & 53 & & & & \\
\hline Femur & 65 & & & & \\
\hline Tibia & 58 & 2 & & & \\
\hline Metapodial & 36 & & & & \\
\hline Calcaneus & 10 & & & & \\
\hline Astragalus & 5 & & & & \\
\hline Rib & & & & & 29 \\
\hline Vertebra & & & & & 8 \\
\hline Total & 711 & 21 & 12 & 15 & 66 \\
\hline
\end{tabular}

\begin{tabular}{|c|c|c|c|c|c|}
\hline \multirow{2}{*}{ Bone } & \multicolumn{5}{|c|}{ Taxon } \\
\hline & Pterocnemia & Tinamotis & Phoenicopteridae & Chloephaga & Fulica \\
\hline Humerus & & 1 & 13 & 2 & 9 \\
\hline Coracoid & & 2 & 7 & & \\
\hline Scapula & & & 2 & 1 & 1 \\
\hline Ulna & & & 4 & 1 & \\
\hline Carpo-metacarpus & & & 5 & & \\
\hline Tibiotarsus & & & 6 & & 2 \\
\hline Tarso-metatarsus & & 7 & & & 7 \\
\hline Femur & & & 9 & & 2 \\
\hline Phalanges & 2 & & & & \\
\hline Total & 2 & 10 & 46 & 4 & 21 \\
\hline
\end{tabular}

\begin{tabular}{|l|c|c|}
\hline \multirow{2}{*}{ Bone } & \multicolumn{2}{|c|}{ Taxon } \\
\cline { 2 - 3 } & Metriopelia & Bird \\
\hline Phalanges & & 43 \\
\hline Sternum & 17 & \\
\hline \multicolumn{1}{|c|}{ Total } & $\mathbf{1 7}$ & $\mathbf{4 3}$ \\
\hline
\end{tabular}

Table 11. Distribution of material in the Puripica rodent and bird samples. 


\begin{tabular}{|l|c|}
\hline \multicolumn{1}{|c|}{ Taxon } & $\mathbf{N}^{\mathbf{0}}$ \\
\hline Mammals & \\
\hline Camelid & 191 \\
\hline Rodent & 1 \\
\hline Bird & 1 \\
\hline Bone scrap & 3346 \\
\hline \multicolumn{1}{|c|}{ Total } & $\mathbf{3 5 3 9}$ \\
\hline
\end{tabular}

The bird bone is a scapula fragment from a pigeon sized species. The rodent bone is a proximal radius from a Lagidium/Chinchilla.

Tabla 12. Distribution of faunal remains in the Tulan 51 sample.

\begin{tabular}{|c|l|}
\hline \multicolumn{1}{|c|}{ Taxon } & \multicolumn{1}{c|}{$\mathbf{N}^{\mathbf{0}}$} \\
\hline Mammals & \\
\hline Camelids & 12096 \\
\hline Rodents & 1849 (does not Include unidentified fragments) \\
\hline Birds & 68 (does not include unidentified fragments) \\
\hline Bone scrap & 45249 (excludes the samples from 2 squares) \\
\hline Total & $\mathbf{5 9 2 6 2}$ \\
\hline
\end{tabular}

Table 13. Distribution of faunal remains in the Tulan 52 sample.

\begin{tabular}{|c|c|c|c|c|}
\hline \multirow{2}{*}{ Bone } & \multicolumn{4}{|c|}{ Taxon } \\
\hline & Lapidium/Chinchilla & Ctenomys & Abrocoma & Phylottis \\
\hline Mandible & 550 & 139 & 3 & 4 \\
\hline Maxilla & 255 & 103 & 5 & 1 \\
\hline Crania & 56 & 11 & & \\
\hline Scapula & 63 & 1 & & \\
\hline Humerus & 79 & 5 & & \\
\hline Ulna & 33 & 2 & & \\
\hline Radius & 17 & 2 & & \\
\hline Innominate & 135 & 10 & & 1 \\
\hline Femur & 129 & 3 & & \\
\hline Tibia & 61 & 1 & & \\
\hline Total & 1558 & 277 & 8 & 6 \\
\hline \multirow{2}{*}{ Bone } & \multicolumn{4}{|c|}{ Taxon } \\
\hline & Tinamotis & Podicipediformes & Phoenicopteridae & Metriopelia \\
\hline Humerus & 6 & & 12 & 1 \\
\hline Ulna & 1 & & 2 & \\
\hline Coracoid & & & 9 & 1 \\
\hline Tibiotarsus & 3 & & 4 & \\
\hline Tarso-metatarsus & 1 & 1 & 1 & \\
\hline Femur & & & 8 & \\
\hline Sternum & 3 & & & 15 \\
\hline Total & 14 & 1 & 36 & 17 \\
\hline
\end{tabular}

Table 14. Distribution of skeletal representation in the Tulan 52 rodent and bird sample. 
due Betty Meggers and the late Clifford Evans for encouraging my work in Northern Chile. Storrs Olsen and Gary Morgan provided invaluable aid in the identification of the material. My wife, Paula Wapnish, accompanied me on my first trip to San Pedro de Atacama. She is responsible for much of the work in identifying and recording the collections as well as preparing the first results of the analysis. Finally we offer our thanks to the Olmos family, and of course the late Father Le Paige, for all their aid during our stay in San Pedro.

\begin{tabular}{|l|c|}
\hline \multicolumn{1}{|c|}{ Taxon } & $\mathbf{N}^{\mathbf{0}}$ \\
\hline Mammals & \\
\hline Camelid & 141 \\
\hline Rodent & 20 \\
\hline Bird & 1 \\
\hline Bone scrap & 415 \\
\hline \multicolumn{1}{|c|}{ Total } & $\mathbf{5 7 7}$ \\
\hline
\end{tabular}

Table 15. Distribution of faunal remains in the Tulan 54 sample.

\begin{tabular}{|c|c|c|c|c|c|}
\hline Bone & Lagidium/Chinchilla & Ctenomys & Phylottis & Rodent & Metriopelia \\
\hline Mandible & 6 & & & & \\
\hline Maxilla & 3 & 1 & & & \\
\hline Teeth & & & 1 & & \\
\hline Scapula & 1 & & 1 & & \\
\hline Humerus & 1 & & & & \\
\hline Radium & 1 & & & & \\
\hline Innominate & 2 & & & & \\
\hline Tibia & 1 & & & & \\
\hline Atlas & 1 & & & & \\
\hline Sternum & & & & & 1 \\
\hline Shaft fragments & & & & 1 & \\
\hline Total & 16 & 1 & 2 & 1 & 1 \\
\hline
\end{tabular}

Table 16. Distribution of skeletal representation in the Tulan 54 rodent and bird sample.

\begin{tabular}{|c|c|}
\hline \multicolumn{1}{|c|}{ Taxon } & $\mathbf{N}^{\mathbf{0}}$ \\
\hline Mammals & \\
\hline Camelid & 68 \\
\hline Rodent & 85 \\
\hline Bird & 13 \\
\hline Bone scrap $\quad$ Total & 723 \\
\hline \multicolumn{2}{|c|}{$\mathbf{8 8 9}$} \\
\hline
\end{tabular}

Table 17. Distribution of faunal remains in the Tulan 55 sample. 
BRIAN HESSE

\begin{tabular}{|c|c|c|c|c|c|}
\hline \multirow{2}{*}{ Bone } & \multicolumn{5}{|c|}{ Taxon } \\
\hline & Lagidium/Chinchilla & Ctenomys & Phylottis & Rodent & Metriopelia \\
\hline Mandible & 7 & 2 & 28 & & \\
\hline Maxilla & 3 & 5 & 5 & & \\
\hline Crania & 1 & & 3 & & \\
\hline Beak & & & & & 5 \\
\hline Teeth & 5 & 7 & & & \\
\hline Scapula & 3 & & & & 1 \\
\hline Humerus & 1 & 1 & 1 & & \\
\hline Radius & & & 1 & & \\
\hline Coracoid & & & & & 1 \\
\hline Innominate & & & 1 & & \\
\hline Tibia & 2 & & 1 & & \\
\hline Femur & & & 2 & & \\
\hline Rib & & & & 2 & \\
\hline Sternum & & & & & 6 \\
\hline Shaft fragment & & & & 4 & \\
\hline Total & 22 & 15 & 42 & 6 & 13 \\
\hline
\end{tabular}

Table 18. Distribution of skeletal representation in the Tulan 55 rodent and bird samples.

\begin{tabular}{|l|l|}
\hline \multicolumn{1}{|c|}{ Taxon } & \multicolumn{1}{c|}{$\mathbf{N}^{\mathbf{0}}$} \\
\hline Mammals & 34 \\
\hline Camelid & 2 \\
\hline Ovis/Capra & 13 \\
\hline Rodents & 1 (Dusicyon) \\
\hline Carnivores & 1 \\
\hline Bird & 544 \\
\hline Bone scrap & $\mathbf{5 9 5}$ \\
\hline Total &
\end{tabular}

Table 19. Distribution of faunal remains from Tulan 56.

\begin{tabular}{|l|c|c|c|}
\hline \multirow{2}{*}{\multicolumn{1}{|c|}{ Bone }} & \multicolumn{3}{|c|}{ Taxon } \\
\cline { 2 - 4 } & $\begin{array}{c}\text { Lagidium/ } \\
\text { Chinchilla }\end{array}$ & Ctenomys & Tinamotis \\
\hline Mandible & 3 & 1 & \\
\hline Maxilla & 1 & & \\
\hline Crania & & 1 & \\
\hline Scapula & 2 & & \\
\hline Humerus & 1 & & \\
\hline Innominate & 2 & & \\
\hline Tibia & 2 & & \\
\hline Tarso-metatarsus & & & 1 \\
\hline \multicolumn{1}{|c|}{ Total } & $\mathbf{1 1}$ & $\mathbf{2}$ & $\mathbf{1}$ \\
\hline
\end{tabular}

Table 20. Distribution of skeletal representation in the Tulan 56 rodent and bird sample. 


\section{REFERENCIAS CITADAS}

BINFORD, L., 1980. Bones. Academic Press, Nueva York.

BOLTON, R., 1979. Guinea pigs, protein and ritual. Ethnology 18 (3): 229-252.

DRUSS, M., 1977. Environment, subsistence economy, and settlement patterns of Chiu Chiu Complex ca. 2700 to 1600 BC) of the Atacama Desert, Northern Chile. Ph. D. Diss., Columbia University.

GILBERT, A. S., 1979. Urban taphonomy of mammalian remains from the Bronze Age Godin Tepe, Western Iran. Ph D. Diss., Columbia University.

HESSE, B., 1982a. Bias in the zooarchaeological record: Suggestions for interpretation of bone counts in faunal samples from the Plains. Smithsonian Contributions to Anthropology 30: 157-172.

- 1982b. Animal domestication and oscillating climates. Journal of Ethnobiology 2 (1): 1-15.

1982c. Archaeological evidence for camelid exploitation in the Chilean Andes. Säugetierekunde Mitteilungen 30 (3): 201-211.

LJZEREEF, G. F., 1978. Faunal remains from the El Abra rock shelter. Palaeogeography, Palaeoclimatology, Palaeoecology 25: 163-177.

MEYER DE SCHAUENSEE, R., 1970. A guide to the birds of South America. Livingston Publishings Co., Wynnewood.
NUÑEZ, L., Ms. Paleoindian and Archaic cultural periods in the arid and semiarid regions of north Chile.

PEARSON, O. P., 1951. Mammals in the highlands of Southern Peru. Bulletin of the Museum of Comparative Zoology 106 (3): 117-174.

- 1959. Biology of the subterranean rodents, Ctenomys, in Peru. Memorias del Museo de Historia Natural "Javier Prado", 9: 5-56.

SHOTWELL, J. A., 1958. Intercommunity relationships in Hemphillian (Mid Pliocene) mammals. Ecology 39: 271282.

THOMAS, D. H., 1971. On distinguishing natural from cultural bone in archaeological sites. American Antiquity 36 (3): 366-371.

WALKER, E. P. et al., 1975. Mammals of the world. John Hopkins University Press, Baltimore.

WATSON, J. P. N., 1972. Fragmentation analyses on animal bone sample from archaeological sites. Archaeometry 14 (2): 221-228.

WILKINSON, P. F., 1975. Musk Ox exploitation in the Arctic Paleoeconomy, E. S. Higgs (Ed.). Cambridge University Press, Cambridge. 